\title{
A advertência poética de Hilda Hilst em As aves da noite
}

\author{
Rubens da Cunha ${ }^{1}$
}

\section{A morte da poesia como advertência}

Entre 1967 e 1969, Hilda Hilst escreveu suas oito peças teatrais: ${ }^{2} A$ empresa, $O$ rato no muro, $O$ visitante, Auto da barca de Camiri, As aves da noite, $O$ novo sistema, $O$ verdugo e $A$ morte do patriarca. Analisaremos aqui a peça As aves da noite, um denso libelo contra o totalitarismo nazista, que revela o olhar hilstiano sobre o encarceramento, a violência e a desumanização.

Nos arquivos de Hilda Hilst encontra-se o seguinte texto datilografado:

Anatol: De início quis fazer dessa peça, uma advertência. Quando a escrevi há meses atrás, o $\mathrm{NPD}^{3}$ já estava a toda, mas ainda não havia conquistado uma boa vitória. Conquistou-a agora, recentemente. E não acredito que tenha sido pelas manifestações da esquerda, não. As pessoas com quem eu conversava, diziam-me que eu estava louca e que nada disso (o neonazismo) estava acontecendo na Alemanha. É claro que não surgirá necessariamente um novo Hitler (afinal a memória das gentes não é assim tão fraca), mas acredito no espírito revanchista e o neonazismo é mascarado, mas para mim será sempre o espírito nazista. Bem, então a proposição da peça era uma advertência dirigida, mas depois pensando bem entendi que não era necessário esse conjunto de slides no início da peça, porque pela maneira com que tratei o assunto, acho que o meu trabalho é uma advertência a qualquer estrutura política de opressão. E depois não é somente o nazismo que ameaça o mundo. Meus personagens são homens diante de homens numa situação limite. Parti de um fato real: o

\footnotetext{
${ }^{1}$ Doutor em literatura e professor da Universidade do Recôncavo da Bahia (UFRB), Cruz das Almas, BA, Brasil. E-mail: rubensdacunha@gmail.com

${ }^{2}$ Depois desse mergulho na dramaturgia, Hilda não retorna mais ao teatro dentro da forma convencional do gênero.

${ }^{3}$ Referência ao Partido Nacional Democrata Alemão (Nationaldemokratische Partei Deutschlands NPD), de matiz neonazista, fundado em 1964. Em 1966, o NPD conseguiu algum sucesso nas eleições regionais da Alemanha, chegando a ter 2,1\% na Baviera e no Slevig e 3,9\% em Hamburgo (Lapouge, 1966).
} 
padre Maximilean Kovel ${ }^{4}$ existiu e foi condenado a morrer por fome e por sede numa cela porão de Auschwitz. Com ele, mais dez prisioneiros. Foram condenados porque um dos prisioneiros do campo evadiu-se. Claro que ninguém sabe o que se passou naquela cela porque todos morreram. Mas eu pretendi ouvir. E entendo que numa situação extrema o homem adquire uma nova dimensão. É justamente nas situações extremas (morte, amor) que a poesia se faz. Creio que para esse trabalho seria necessário bons atores, de grande maturidade cênica, para que eles criassem a volta de si mesmos, o que o texto exige. Deve haver pausas prolongadas, a tensão, afinal, também é feita de silêncio, ah, como eu queria conversar com você sobre tudo isso. A música que eles cantam é bem bonita, gostaria tanto de ver essa peça encenada, pelo espírito da coisa, você compreende? Mas não creio que exista a possibilidade (Hilst. HH.II.III. 6.1.0004).

Essa reprodução da carta direcionada a Anatol Rosenfeld apresenta algumas das preocupações de Hilda Hilst, sobretudo quando reafirma a ideia de "advertência". Suas peças teatrais seriam, assim, como um verter contínuo de avisos e observações para o público. A advertência, em As aves da Noite, vai além da questão do nazismo, avança sobre a questão da ditadura e do estado totalitário pelo qual passava o Brasil no período da escrita das peças. Não por acaso, a frase final da carta apresenta um certo desânimo: "gostaria tanto de ver essa peça encenada, pelo espírito da coisa, você compreende? Mas não creio que exista a possibilidade." 5 Berta Waldman, num ensaio sobre As aves da noite inicia sua reflexão falando de como Hilda Hilst foi precursora nesse tema no teatro brasileiro, mas não se deteve somente nele:

Em As Aves da noite (1968), texto que é objeto de minha análise, Hilda Hilst mostra-se precursora no que diz respeito à matéria escolhida. Sua peça passa-se em Auschwitz e se refere ao Holocausto, num momento em que poucos o tematizavam na literatura brasileira. A peça parece apontar para dois lados distintos, porém concomitantes: ao referir-se à grande ferida não

\footnotetext{
${ }^{4}$ Hilda Hilst datilografa o nome incorretamente. Trata-se do Pe. Maximilian Kolbe. De acordo com o site do Vaticano, o Pe. Kolbe foi beatificado em 17 de outubro de 1971. Em 10 de outubro de 1982, o Papa João Paulo II proclama a canonização de Maximilian Kolbe. Disponível em: <https://goo.gl/qsgyy3>. Acesso em: 7 jul. 2014.

${ }^{5}$ A peça só chegaria aos palcos em 1980, sob a direção de Antônio do Vale.
} 
cicatrizada da Segunda Guerra Mundial, a peça alude também, na minha leitura, à ditadura brasileira (Waldman, 2007, p. 1).

As Aves da noite é um exercício concentrado de tensão. A começar pela forma como o cenário foi concebido. Trata-se de um cilindro de altura variável, que dependeria da altura do teatro. Dentro desse cilindro há a cela, com 1,90 m de altura. O público fica em volta do cilindro, no entanto, Hilda pede que as cadeiras sejam isoladas por algum tipo de divisão. Em uma nota ela explica: "idealizei o cenário de As aves da noite de forma a conseguir do espectador uma participação completa com o que se passa no interior da cela. Quis também que o espectador sentisse total isolamento, daí as cadeiras estarem separadas por divisões" (Hilst, 2008, p. 231). Na carta mencionada anteriormente, Hilda reescreve algumas ideias que havia colocado em duas breves introduções feitas na peça. Na primeira, novamente a afirmação e firmação pelo poético:

Com As aves da noite, pretendi ouvir o que foi dito na cela da fome, em AUSCHWITZ. Foi muito difícil. Se os meus personagens parecerem demasiadamente poéticos é porque acredito que só em situações extremas é que a poesia pode eclodir VIVA, EM VERDADE. Só em situações extremas é que interrogamos esse GRANDE OBSCURO que é Deus, com voracidade, desespero e poesia (Hilst, 2008, p. 233).

$\mathrm{Na}$ outra introdução, Hilda explica de onde vem a motivação da peça: trata-se de uma história que ela decidiu recontar, abrindo os ouvidos ao silêncio desesperado que vinha desse lugar e deixando acontecer uma possibilidade de diálogo, de reflexão, de abertura para que, não apenas seu texto chegasse ao fundo desse desespero, mas que também seu público pudesse entregar-se, pudesse ter olhos e ouvidos engajados ao ser advertido de que tais barbáries não podem ser repetidas, em nenhum grau.

Do campo de concentração fugiu um prisioneiro. Em represália os SS, por sorteio, condenaram alguns homens a morrer no Porão da Fome. Figurava entre os sorteados o prisioneiro $\mathrm{n}^{\circ} 5.659$, que começou a chorar. O padre católico franciscano, Maximilian Kolbe, prisioneiro $\mathrm{n}^{\mathrm{o}} 16.670$, se ofereceu para ocupar o lugar do $\mathrm{n}^{0} 5.659$. Foi aceito. Os prisioneiros foram jogados numa cela de concreto onde ficaram até a morte. O que se passou no chamado Porão da Fome ninguém jamais soube. A cela é hoje um monumento. Em 24 
de maio de 1948, teve início, em Roma, o processo de beatificação do Padre Maximilian Kolbe (Hilst, 2008, p. 237).

Entre essas duas breves introduções, Hilda Hilst coloca também uma citação bastante significativa, vinda de um livro de autoria de Maria Winowska que conta a história de Maximilian Kolbe, no qual se lê: "a tortura da fome faz descer o homem ao nível do animalesco, pois a resistência humana tem os seus limites... além dos quais só restam o desespero ou a santidade" (Winowska apud Hilst, 2008, p. 235). Dessa forma, Hilda pede para que haja uma "comoção intensa, desespero e delírio fundem-se frequentemente" (Hilst, 2008, p. 239).

Como é comum nas peças de Hilst, temos personagens que são reconhecidos por sua função ou por seu gênero. Estão na cela com Kolbe: o jovem Poeta, de 17 anos e com aspecto extremamente frágil; um Estudante, com 20 anos; e um Joalheiro, também frágil e com 50 anos. Além disso, há o Carcereiro, que, no caso, é um prisioneiro judeu, com 40 anos e aparentando mais vigor. Três outros personagens compõem a peça: uma mulher de 30 anos, trazida à cena mais para o final. Um agente da SS e Hans, um ajudante da SS. Num primeiro momento, tudo é escuridão, ouvem-se apenas as vozes de um agente da SS e do Padre Kolbe, que se oferece para ir no lugar do outro prisioneiro escolhido para o castigo imposto pelos nazistas. Depois do escuro e do silêncio, entra uma luz em resistência, que é um tipo de luz que entra ou sai lentamente da cena. Com essa luz há um descortinamento lento e gradual daquelas pessoas presas na cela da fome. A cena se inicia com um diálogo entre o poeta, o estudante e o joalheiro. Os dois últimos pedem que o poeta continue a dizer um poema. O Poeta, então, fala lentamente:

POETA (fala o poema tocando-se, olhando-se. Tenso. Comovido):

E deste morto me aproximo

CARCEREIRO (objetivo) Você ainda não está morto.

POETA (lento):

Curvo-me sobre o que foi rosto. Oval em branco.

Pálpebra remota

Boca disciplinada para o canto. O braço longo

Asa de ombro... Amou. Corroeu-se de sonhos.

E cúmplice de aflitos, foi construído e refeito

Em sal e trigo.

(muda levemente o tom. Sorri)

O ventre escuro não gerou, 
(grave)

Talvez por isso

Teve mãos desmedidas

E o grito exacerbado foi o verso. Amou. Amou.

(fala mais rapidamente, olhando-se)

Tem os pés de criança: altos e curvados.

O corpo distendido como lança. É inteiriço e claro.

(sem pausa. Voz grave. Exaltada de início até a palavra "hora". Depois mais branda)

Ah, tempo extenso, grande tempo sem fim onde me estendo

Não para contemplar este todo de fora

Olhar enovelado respirando a hora...

Antes o olhar suspenso como um arco,

Olho dentro da fibra que o circunda, cesta mortuária.

CARCEREIRO (objetivo): Você ainda não está morto.

POETA (mantém o mesmo tom):

Depois a noite, corpo imenso...

E a palha do meu nome...

(voz alta como um chamamento)

Que verso te recompõe?

Que fibra te comove ainda?

(voz baixa)

O mundo, o mundo...

O corpo que se move

Na pretensa carcaça de um molusco.

Toca-o. Ele se encolhe mudo.

(encolhendo-se) (Hilst, 2008, p. 243/244).

Eis o poeta ditando aos outros o seu estar no mundo, seu curvar-se sempre sobre o próprio corpo e ver as mãos desmedidas, o exacerbado grito que foi o verso, o ventre infértil, o sempre olhar suspenso. É um poeta, preso ao corpo, da mesma forma que está preso na cela da fome, e que traz aos outros prisioneiros o duelo entre a necessidade de pertencer e contemplar "este todo de fora" e enovelar-se para dentro, buscar outras paragens menos sórdidas. Nesse momento, o Pe. Maximilian ainda está isolado e ajoelhado fora do centro da cela. Ele é questionado pelo Poeta, que exaltado, lhe pergunta: "Por quê? Por quê? Por que você escolheu esta nossa morte quando podia ter a vida? Ainda que fosse aquela... era a vida. Que força te conduziu a isso? Por quê? (pausa)". Maximilian não 
sabe, alega que lhe foi dada uma força, talvez Deus, talvez o amor. Depois de uma interrupção sarcástica do agente da SS, que diz "o tempo não passa, não é?", Maximilian, o Poeta e o Carcereiro estabelecem seus pontos de vista frente ao que estão sofrendo.

MAXIMILIAN (lento): Luz infinitamente poderosa.

POETA (interrompendo): Noite infinitamente escura.

CARCEREIRO (interrompendo): Noite podre!

MAXIMILIAN (interrompendo com voz firme): Luz infinitamente

poderosa, dai-nos a Tua força, a Tua misericórdia, o Teu amor

(Hilst, 2008, p. 247).

Maximilian traz a fé como força para suportar e talvez entender toda a situação extrema que eles estão vivendo. Kierkegaard (s.d., p. 83) afirma que "a coragem da fé é o único ato de humildade" e o que tocará o Padre, em toda a peça, é a busca pelo entendimento de sua própria humildade e de seu irrestrito amor a Deus. Kolbe também se debate com o paradoxo que é o amor divino, que pode ser visto aqui sob a ótica de Simone Weil, ela mesma uma mulher cuja biografia é plena de atos radicais no exercício da fé e da humildade:

A necessidade inflexível, a miséria, a angústia, o peso esmagado da necessidade e do trabalho que esgota, a crueldade, as torturas, a morte violenta, a sujeição, o terror, as enfermidades: tudo isso é o amor divino. É Deus que por amor se retira de nós para que possamos amá-lo, pois se estivéssemos expostos à irradiação direta de seu amor, sem a proteção do espaço, do tempo e da matéria, seríamos evaporados como a água no sol (Weil, 1986, p 88).

Por outro lado, o Carcereiro é aquele que opta pelo pessimismo, ou por uma revolta niilista que o atravanca e o coloca como um antagonista dentro da cela, pois, diante da fé de Kolbe, ele sempre se opõe com os limites do racionalismo. No entanto, é no Poeta que se encontra a voz mais complexa dessa peça. Ele é jovem, descrente no Deus de Kolbe, tem o corpo mais frágil dos prisioneiros e se coloca na cela como aquele que tenta trazer alguma beleza, alguma poesia a esse emaranhado de crueldade e morte. Assim, nessa peça, é através do Poeta que podemos ver uma imagem do século $X X$ alquebrado pela barbárie.

Alain Badiou (2007, p. 18) diz que o século XX inicia com uma "largada excepcional". O período entre 1890 e 1914 foi como um "renascentismo", período de criatividade polimorfa, tempo prodigioso de nascimentos e rupturas. Mallarmé, Freud, Schoenberg, Proust, James Joyce, Wittgenstein, 
Picasso, Braque, Husserl, Fernando Pessoa, Griffith e Chaplin são alguns exemplos de nomes que começaram ou desenvolveram suas ideias nesse período. A pergunta que segue é: o que aconteceu? Por que todo esse processo inovador se perdeu diante da primeira guerra, todo um período de recessão, e depois ainda outra grande guerra e, por fim, esse nosso tempo de agora com grandes avanços tecnológicos e científicos, porém cada vez mais dominado por sistemas invisíveis como o mercado e o lucro, além de inúmeras guerras que, se não ganharam o epíteto de mundiais, conseguiram ser tão sangrentas quanto. Sobre essas questões e ao tentar entender como um século que nasce aparentemente tão promissor parte para um processo contínuo de conflitos, guerras, extermínios, exclusões de toda ordem, Badiou afirma:

Admitamos que nosso século seja aquele em que, como dizia Mauraux, a política tornou-se a tragédia. O que no começo do século, na largada dourada da Belle Époque, preparava essa visão das coisas? No fundo, a partir de certo momento, o século foi obcecado pela ideia de mudar o homem, de criar o homem novo. [...] Criar o homem novo equivale sempre a exigir que homem seja destruído (Badiou, 2007, p. 21).

Dessa forma, tanto o fascismo quanto o comunismo, bem como o atual desenvolvimento científico, querem criar o homem novo e, claro, tudo passa pela destruição, pelo extermínio do homem velho. A problemática do que seja a vida é fundamental no século XX: "Vida e História são dois nomes para a mesma coisa: o movimento que arrebata da morte, o devir da afirmação", diz Badiou (2007, p. 31). A visão sobre o século mantém a ideia de que o coletivo é maior que o indivíduo. Trata-se de um século em que o animal humano, como "ser parcial transcendido pela vida", tem que lutar contra a ideia hegeliana de História. $\mathrm{O}$ homem do século deve confrontar-se com a História, "dominá-la politicamente". Badiou (2007, p. 32-33) diz que esse enfrentamento é categórico, que mesmo a história sendo uma besta enorme e poderosa que nos supera "é preciso suportar seu olhar de chumbo, e forçá-la a nos servir".

Há, portanto, uma disputa ente vida e vontade. E no século $X X$ a vida só cumpriu seu destino e seu desígnio positivo através do terror. O problema do século-besta é a vida, porém uma vida que vomita sangue e morte. Trata-se de um século obsessivo com seu próprio horror. E um século de grandes matanças e de grandes promessas, porém as promessas não foram cumpridas. Uma ideia que atravessou o século foi a de "que 
sua oportunidade já passara. Que ele só podia decidir realizar uma penosa reparação de sua impotência". O século foi então marcado por duas perspectivas: a primeira é a de que ele confirmaria e cumpriria as promessas do século XIX; a segunda é a de que haveria uma ruptura com o século XIX, fazendo do século XX uma barbárie, um pesadelo. No primeiro caso, é preciso aceitar o horror do real. Alguns acreditam que todo o horror perpetrado no século $X X$ foi feito em nome de uma promessa de um mundo melhor. Badiou (2007, p. 39) pensa o contrário: tudo passa pela fascinação do real nesse século. Não havia ingenuidade, mas aceitação da experiência do horror. Lacan viu que a experiência do real sempre é em parte experiência do horror. Para Hilda, também não havia a possibilidade de vir a nascer um mundo melhor pelo horror.

Em As aves da noite, Hilda usa um expediente comum às outras peças: seus personagens contam histórias ou "estórias", e é por elas que se inicia alguma reflexão. Logo no início, o Estudante fala de pessoas que criam gatos num quarto completamente escuro, e em certo dia soltam o bicho numa manhã de sol. Ao ouvir a história, Maximilian tenta encontrar uma justificativa e atribui ao medo das pessoas a existência de tais atos. Enquanto o carcereiro é irônico e não perdoa qualquer justificativa para o horror:

CARCEREIRO (com ironia e alguma agressividade): Muito bem, Maximilian. Muito bem. $\mathrm{O}$ medo então. $\mathrm{O}$ medo naqueles que enlouquecem o gato, no próprio gato, em todos. O medo sempre. Muito compreensível. Dá bem para entender. O medo para tudo em todos. Muito bom (Hilst, 2008, p. 245).

O Estudante também fala de uma experiência que se faz com os falcões:

Vocês sabem... fizeram um dia uma experiência com o falcão (pausa) [...].6 Puseram carne dentro de uns tubos de metal e fizeram o falcão engolir. [...] Para investigar o processo digestivo. [...] (olhando à volta da cela) Os tubos eram fechados nos dois lados por umas telinhas de arame [...] para deixar passar qualquer suco do estômago [...] o falcão era obrigado a engolir esses tubos mas depois punha pra fora (Hilst, 2008, p. 248).

\footnotetext{
${ }^{6}$ As chaves são usadas aqui para suprimir as falas ditas pelos outros personagens enquanto o Estudante conta a sua história. Trata-se de perguntas ou observações que não interferem na história contada.
} 
Mais uma vez, é a partir de uma história contada por um personagem que se abre espaço para uma série de discussões contundentes. Ao se perceberem como a carne no estômago do falcão, a discussão é encaminhada para um problema por certo insolúvel: a existência da alma e a existência da alma naquele que promove e pratica o horror.

MAXIMILIAN (com firmeza): Mas "Nós" temos alma.

CARCEREIRO (voz alta): Alma, Maximilian, só você é que tem.

MAXIMILIAN (em comoção): Todos nós temos alma.

Ouvem-se risos fora da cela.

JOALHEIRO (referindo-se aos SS. Ferino): Eles também?

MAXIMILIAN: Todos nós. Todos nós.

CARCEREIRO (colérico, voz baixa): Maximilian, você quer me dizer que esses filhos da puta tem alma? O que é a alma então? O que é? Eu não posso ter nada que eles têm (Hilst, 2008, p. 249).

Este é um dos embates colocados dentro da cela da fome por Hilda Hilst. Simone Weil (1986, p. 138) dizia que "o inocente que sofre sabe a verdade sobre seu verdugo, mas o verdugo não", ou seja, "o inocente só pode conhecer o mal como sofrimento, é somente o inocente quem pode sentir o inferno". Assim, mesmo sofrendo toda violência dessa execução lenta, Maximilian ainda vê o nazista como um homem, alguém que tem em si alma, mas, se seguirmos a lógica de Simone Weil, não tem sensibilidade, não conhecerá a inocência e tampouco o sofrimento. Por outro lado, fica o Carcereiro, com sua negativa peremptória de ter ou ser qualquer coisa semelhante a seus algozes, o que se revela também um paradoxo, pois aqueles que andam fora da cela, cheios de poder e violência, são humanos iguais a ele.

De uma forma ou outra, é preciso lidar com a ferida da violência nazista, (ou de qualquer outro sistema totalitário, como vimos na carta que Hilda escreveu a Anatol Rosenfeld), e percebê-la como um processo feito e executado pela inteligência humana. A força de As aves da noite é que os personagens estão presos no porão da fome e também presos às suas verdades, aos seus dogmas, e todos enfrentando aquilo que comumente se chama de inominável, de impensável, mas que para Badiou tem que ser visto como um pensamento, articulado, muito racional:

Permitam-me fazer a pergunta hoje provocante, e mesmo proibida, que é a seguinte: qual era o pensamento dos nazistas? [...] Existe uma maneira de voltar sempre pesadamente ao que os nazistas fizeram (procuraram exterminar os judeus da Europa nas câmaras de gás) que impede totalmente qualquer acesso ao que 
eles pensavam ou imaginavam que pensavam ao fazer isso (Badiou, 2007, p. 14).

Badiou (2007, p. 14) afirma que, se não pensarmos naquilo que pensavam os nazistas, isso nos impedirá de pensar naquilo que faziam. E esse "não pensar" impossibilita qualquer política real de banimento de tais ideias. Por isso, pensar em toda a força nazista como algo impensável, ou indizível é como que inocentar o nazismo, que foi sim um pensamento articulado, planejado, executado com cuidado e zelo.

Afastar o nazismo, ou qualquer outra política unitária, da ideia de barbárie ou de mal absoluto é uma forma de enfraquecer esse movimento. Seria preciso sempre trazer para o campo do pensamento esses movimentos, pois só assim se conseguiriam os meios adequados para julgá-los. Ao lançar a barbárie para fora do pensamento, além de inocentar a barbárie, há também um discurso implícito de inocência da razão. Badiou explica:

Os que afirmam que o nazismo não é pensamento ou que não é (contrariamente à "democracia" deles) política, querem apenas inocentar o pensamento ou a política. Isto é, camuflar a aliança secreta e profunda entre o real político do nazismo e o que entendem ser a inocência democrática (Badiou, 2007, p. 15).

A discussão sobre a alma é interrompida pelo lamento do poeta, o qual diz que não aguentará, assim como o Joalheiro também grita o desespero da morte iminente. Maximilian Kolbe resolve então pedir para que todos falem uns com os outros, pois ele acredita nos afagos da palavra, da conversa, da oralidade: "(para todos) Escutem... se nós falarmos... um com o outro... assim... (com vergonha de dizer a palavra) tranquilamente, tudo será mais fácil." Maximilian abre a sua história: quando entrou no seminário, acreditava que Deus se mostraria nas orações, que ele teria sensações só pelo ato de rezar - "quem sabe... se até visões eu teria" (Hilst, 2008, p. 252) -, mas nada aconteceu ao coração da Maximilian, até que ele percebe a necessidade de não ter nenhum conforto, para quem sabe, neste caminho inverso se chegar a Deus:

MAXIMILIAN (interrompe com grande comoção): Mas depois senti que era preciso que eu não tivesse nenhum conforto, que Deus queria que a minha oração fosse lúcida, clara, que era preciso rezar com olhos bem abertos, que dentro de mim tudo ficasse nítido, limpo (Hilst, 2008, p. 254).

Ao se afastar da vontade, do desejo, Maximilian encontra um caminho para se aproximar de Deus. Não por acaso, é o único entre os 
presentes que escolheu essa situação. A liberdade de escolher a morte, esse morrer pelo irmão, princípio utopicamente cristão, faz com que Maximilian não seja deveras compreendido. Há sempre uma aura de acusação, de indignação nos outros que não tiveram a escolha. Essa discussão também é interrompida pelo Poeta, que agora está passando por uma dificuldade intestinal. Ao se ver envolto em dor e fezes, questiona-se: "O que é o corpo? O que é o corpo?", mais adiante, o poeta suplica: "Maximilian, eu não quero este meu corpo, eu não quero mais! Faz alguma coisa para que ele se acabe depressa, faz alguma coisa para que eu não saiba dele mais" (Hilst, 2008, p. 256).

Para aumentar a tensão na cela da fome, os nazistas inserem uma mulher, forjando outros limites para a barbárie, dessa vez não apenas éticos, políticos, religiosos, mas que envolvem a presença de um corpo ainda mais fragilizado: o corpo feminino, que poderá ser vilipendiado também sexualmente. A longa fala que Hilda Hilst concede à SS dá a dimensão de que o mal pode estar dentro da ótica de Simone Weil citada acima, na qual afirma a insensibilidade do verdugo. E, para aumentar a carga dramática desse sólido pedaço de inferno que é a cela da fome, Hilda Hilst coloca em cena um agente da SS entre a suavidade e malignidade contundente:

A porta é aberta com suavidade. Demoram um pouco par entrar. Ouve-se o SS dizente: "Você já vai ver, entra, você vai gostar". Uma voz de mulher: "Mas para quêe?" Voz do SS empurrando a Mulher para dentro da cela! "Entra!". Entram, também, o ajudante e o SS.

SS (delicado): Boa noite, senhoras. (para a Mulher) Vamos, dê boa noite aos porcos. Vamos (safanões) diga: boa noite, porcos.

MULHER (timidamente): Boa noite.

SS (gritando): Porcos! Diga (acentua) porcos.

MULHER: Boa noite (safanão pesado), porcos.

SS: (delicado, para os prisioneiros): Já é noite, sabiam? E a noite é feita para que mesmo? (risadas discretas de Hans) Para quê? (pausa) Para foder, porcos. (risada alta. Muda o tom de voz para a Mulher) Vai. Primeiro o que está cagado. (empurra a Mulher mas simultaneamente puxa) Não, não, primeiro nosso amigo de batina. (ri) De batina, Hans! $\mathrm{O}$ que escolheu a merda, a morte e agora (delicadamente) o amor. (aproxima-se de Maximilian que o olha fixamente. Ameaçando, lentamente) Abaixa os olhos, abaixa os olhos... (delicado) Então, uma cadela judia para passar a noite não é nada mau, hein? Será que Deus vai gostar? (risadas discretas de Hans) Vai sim... nós acreditamos em Deus 
também... O nosso Deus é o Deus dos justos. (para a Mulher) Vamos, pelo menos dá um beijinho nele para gente ver. (A Mulher hesita. $O$ SS empurra violentamente a Mulher na direção de Maximilian) Beija esse de batina, vamos! (A Mulher beija Maximilian, que lhe sorri) Ele está gostando, Hans! (morre de rir) Ele está gostando! Quer ver que os porcos são até capazes de foder! (ainda rindo dirige-se à Mulher antes de sair) Você fica. (A mulher olha o SS como que interrogando) Você fica. (pausa longa. Tensão) (Hilst, 2008, p. 258).

A mulher é deixada na cela. Começa uma longa cena, na qual o Carcereiro quer que a Mulher conte o que ela fazia lá fora. A cena prossegue e a mulher vai aos poucos contando como fazia a limpeza na câmera de gás. Apenas o Carcereiro de forma agressiva insiste em saber de tudo. Entramos em outra seara: o testemunho, a impossibilidade do testemunho e a vergonha.

MULHER: Mas eu tenho de contar? Por quê?

CARCEREIRO (com ironia): Para que a gente se lembre mesmo depois da morte, sempre, sempre, porque se morrerem todos, a tua palavra vai ficar viva no espaço, viva, você não entende?

ESTUDANTE: A palavra tem vida?

POETA (tentando acreditar no que diz): Um dia quem sabe a palavra se transforma em matéria... e tudo o que ela falar vai ficar assim... imagem... viva, isso mesmo, imagem viva diante dos olhos de todos... e então os que vierem serão obrigados a se lembrar de nós... (para o Carcereiro) Não é isso? (Hilst, 2008, p. 260).

Muito se fala e se pensa a respeito dos sobreviventes das guerras, e mais especificamente dos sobreviventes dos campos de concentração, sobretudo o mais letal deles: Auschwitz. Trata-se de um enfrentamento difícil, complexo. Primo Levi fala que as verdadeiras testemunhas do que aconteceu não são os sobreviventes, mas os "mulçumanos" $: 7$ "quien lo ha hecho, quien ha visto a la Gorgona, no ha vuelto para contarlo, o ha vuelto mudo; son ellos, los 'musulmanes', los hundidos, los verdaderos testigos, aquellos cuya declaración habría podido tener un significado general. Ellos son la regla, nosotros la excepción" (Levi,

\footnotetext{
7 “A todos los Lager era común el término Muselmann, 'musulmán' atribuido al prisionero irreversiblemente exhausto, extenuado, próximo a la muerte. Se han propuesto dos explicaciones, ambas poco convincentes: el fatalismo, y los vendajes de la cabeza que podían asemejarse a un turbante. Tiene su reflejo exacto, incluso con su cínica ironía, en el término ruso literalmente 'llegado a su fin', 'concluido"” (Levi, 2000. p 42).
} 
2000, p. 36). Essas pessoas, segundo Levi, semanas antes da morte corporal já haviam perdido a capacidade de observar, recordar, refletir, expressar-se, assim, os sobreviventes falariam por eles por delegação. No pequeno microcosmo criado por Hilda Hilst ainda não existem os Muselmann, de uma forma ou de outra, eles ainda se apegam a alguma esperança, no caso a esperança de que a palavra possa ficar no ar, possa um dia se materializar e possa trazê-los de volta à vida.

A cena prossegue com a mulher narrando suas atividades. Diferente das outras narrativas que constituem As aves da noite, esta é uma narrativa que invoca um lugar, um cenário conhecido. Eles não podem fugir para o passado mítico proposto pelo Poeta, ficam presos à narrativa da Mulher que limpa os fornos e testemunha o que acontece lá dentro, tendo em vista aqui a ideia de Agamben sobre o testemunho ser constituído como um corpo de contrários: “o testemunho é uma potência que adquire realidade mediante uma impotência de dizer, e uma impossibilidade que adquire existência mediante uma possibilidade de falar", dessa forma o testemunho seria uma "indivisível intimidade"(Agamben, 2008, p. 147). É sob esses paradoxos que se constitui o testemunho da Mulher, ela, que ainda não é uma "muçulmana", pois não corre em seu corpo nenhuma indiferença. Todo o ato a que se sujeita é sofrido nos extremos. A Mulher narra para os prisioneiros:

MULHER (lentamente, a princípio em tensão, depois adquirindo firmeza durante o relato): Nós usamos botas de borracha... e máscaras contra gás... mangueiras. [...] Eis o sinal para que lancem os cristais pelos respiradouros. [...] Depois as aberturas são seladas. (Eu... e outros... entramos depois de uns trinta minutos... (pausa) Primeiro a gente ... limpa o sangue... as fezes. [...] (agoniada) Depois separamos os corpos. (pausa) [...] Difícil de separar... mas com cordas... com ganchos. (agoniada) Como uma pirâmide, é assim que eles estão juntos à porta de metal, como uma pirâmide toda feita de sangue, de sangue muito escuro (Hilst, 2008, p. 262-266).

Esse testemunho é interrompido diversas vezes pelo Estudante, que tenta cortar o relato com uma história qualquer de infância; pelo Poeta, que diz, nervosamente, um poema, cantando o dia claro que jamais existirá de novo; e por Maximilian, que quer que a mulher pare de falar. Quem exige o depoimento é o Carcereiro, que é, deste conjunto de personagens, aquele que mais recusa o infortúnio - pode-se pensar nele 
como o mais distante da ideia de "muçulmano", apesar de seu pessimismo e da crueldade de sua fala. O carcereiro faz uma pergunta ética à mulher: "e você vive e come... depois disso?" A mulher responde com a intensidade que lhe cabe e faz uma opção radical pela vida a todo custo: "Eu quero viver, eu quero viver... é mais forte do que tudo. (o carcereiro cospe na mulher) Mas eu sou como vocês, eu sou como vocês (para o carcereiro) Eu sou igual a você!"

A Mulher pode ser aproximada dos Sonderkommandos, os judeus que eram selecionados pelos nazistas para fazerem a limpeza dos fornos. Eles tinham apenas um privilégio: alguns meses comiam o que queriam. Eram chamados pelos nazistas de "Esquadra Especial" e, segundo Primo Levi (2000, p. 21), "las Escuadras Especiales no escapabam al destino común; por el contrario, las SS realizaban todas las diligencias oportunas para que ninguno de los hombres que habían formado parte de ellas pudiese sobrevivir y contarlo." Essas pessoas eram escolhidas por sua compleição física ou por um estudo cuidadoso de suas fisionomias e, em raros casos, por castigo.

O Carcereiro não aceita se igualar a Mulher, e quem pode lhe julgar o fato de preservar em si, em seus gestos violentos, alguma dignidade que o mantém vivo também? Por outro lado Maximilian, em seus pendores de se autoanular, de trazer para si a completa humilhação e, também nesses gestos exíguos encontrar alguma força, acolhe a Mulher, que está desesperada, dizendo-se igual a ela, dizendo que é possível que todos ali fizessem o mesmo.

A discussão se encaminha para a inocência de Deus. Ao receber do Carcereiro a pergunta "Deus é inocente?", o padre apenas movimenta a cabeça afirmativamente e fala: "as coisas divinas... as coisas divinas são uma noite infinita para a nossa razão". Atordoadas pela fome e pela morte próxima, as falas exíguas vão tentando estabelecer seus parâmetros de Deus: para o Joalheiro, é algo complicado; para o Poeta, "as coisas de Deus são rendilhadas, muitos caminhos"; para o padre Kolbe, trata-se de apenas um caminho, sem chegarem a nenhuma conclusão a não ser o terror de estarem circunscritos na cela da fome.

A tensão cresce, não apenas pelos contínuos contrapontos que o Carcereiro faz às ideias de Kolbe sobre Deus e o amor, mas também pela aproximação da morte do Poeta. Apesar de Maximilian Kolbe ser o protagonista e sua história biográfica ser o estopim para As aves da noite, é o Poeta que concentra mais dramaticidade. Não por acaso, é da fala do 
Poeta que vem o título da peça, numa discussão sobre a possibilidade de amar os algozes nazistas, o poeta fala: "(lentamente, quase inconsciente): Eles são como certas aves que se feriram nas duas asas... e se você quiser socorrê-las... não saberá como... nem por onde segurá-las. Eles são como certas aves da noite" (Hilst, 2008, p. 269). O Poeta também é aquele que tem mais medo de morrer, ao ver sua juventude interrompida pelo acaso de ter sido um dos escolhidos para o porão da fome, tudo o que o poeta deseja quando está prestes a morrer é desistir dos ideais do amor, seja romântico, platônico, cristão, e entregar-se ao ódio, o mesmo ódio responsável por sua morte: "POETA (desesperado): Então eu não quero, Maximilian, eu não quero morrer em amor, eu quero que o meu ódio cresça a cada dia, que o ódio venha depressa, depressa, eu estou cheio de ódio (grita escondendo a boca nas mãos)" (Hilst, 2008, p. 270).

Podemos pensar novamente no livro de Alain Badiou, que, ao lançar seu olhar sobre o século, traz outra questão que foi uma das obsessões do século XX: "Qual é a função da arte? Que medida comum há entre arte e o século"? Esta era uma das questões que já afligia o século XIX, porém uma das marcas do século XIX foi substituída no século XX: o poeta-guia, cujos arquétipos foram poetas como Victor Hugo ou Walt Whitman. Tal poeta era uma figura de vanguarda, ia à frente com a função de ser uma espécie de despertar dos povos, do progresso, da liberdade. No final do século, esse modelo já estava obsoleto, encontrando sua ruína no século XX. De acordo com Badiou:

Esse século, na linhagem de Mallarmé, funda outra figura, a do poeta como exceção secreta atuante, como reserva do pensamento perdido. O poeta é o protetor, na língua, de uma abertura esquecida; é, como diz Heidegger, o "guardião do Aberto". O poeta, ignorado, monta guarda contra o extravio. E continuamos na obsessão pelo real, já que o poeta garante que a língua conserva o poder de nomeá-lo (Badiou, 2007, p. 41).

Dessa forma, o Poeta muda a sua função, de poeta-guia passa a ser um poeta-vigia, poeta que monta guarda contra o extravio, o poeta capaz de fazer com que a língua mantivesse o poder de nomear o real, pois que está no umbral, está naquele espaço de espera: "esse século foi o de uma poética da espera, de uma poética do umbral. O umbral não será transposto, mas mantê-lo terá valido o poder do poema" (Badiou, 2007, p. 42). Esse poder do poema preserva, segundo Badiou, de três dramas: a liberdade do poema nos livra da prisão do século; a alegria e a unidade 
do poema nos afastam da tristeza e da passividade; e o poema nos livra da traição, que é a ferida da espreita, o veneno. O século é a tentação do pecado absoluto. Contra tudo isso, "existe apenas a flauta da arte", segundo Badiou (2007, p. 41). Assim, o empreendimento de pensamento mais corajoso é "ser de seu tempo, mediante maneira inaudita de não o ser. Para falar como Nietzsche, ter coragem de ser intempestivo. Todo verdadeiro poema é consideração intempestiva" (Badiou, 2007, p. 41).

Em que medida essa peça de Hilda aproxima-se dessas ideias? Primeiramente, sobre essas duas perspectivas - a de que o século cumpriria as promessas do século XIX, ou de que ele romperia completamente com os ideais capitaneados pelo idealismo do século anterior -, o fato é que a obra de Hilda foi permeada por algo que pode se assemelhar a um tardo-romantismo, por uma sensação de perda do ideal. Na escrita de Hilda, o poeta está no umbral, como o "guardião do Aberto", mas ao mesmo tempo é um poeta de luto, pois o século lhe retirou o lugar de poeta-guia. Falta-lhe segurança das verdades universais e sobra-lhe o luto, a dor de ter que cantar um tempo descentrado, relativo. Retomando as duas opções sobre o século, a escrita de Hilda trata o século como ruptura com o ideal e instauração da barbárie. No entanto, o fantasma da promessa não cumprida permanece presentificado, estratificado nessa escrita que é órfã do ideal, do Deus morto. Sloterdijk (2002, p. 66) diz que "declarar muerto a Dios implica, en una cultura condicionada por el monoteísmo, una dislocación de todos los nexos y el anuncio de una nueva forma del mundo." Com a morte de Deus, já não há mais pertencimento comum de todos os homens na unidade de um gênero criado.

Podemos pensar que é sobre essa orfandade que está o Poeta de As aves da noite. Uma orfandade trágica, por certo. Assim, é o jovem Poeta de "17 anos, aspecto extremamente frágil" (Hilst, 2008, p. 239), que, entre todos os personagens, é o único que morre durante a peça. E é justamente a voz desse poeta adolescente, frágil, que enfrenta a força descomunal do século. "Ah, tempo extenso, grande tempo sem fim onde me estendo, não para contemplar este todo de fora, olhar enevolado respirando a hora... Antes o olhar suspenso como um arco." O Poeta é o que traz alguma beleza, no sentido mais clássico, àquele ambiente destituído de luz. Ele é ainda um resquício do poeta-guia, o poeta detentor do ideal, mas que foi atropelado pela máquina pensante de um sistema gigantesco, e se percebe ínfimo, nem sequer guardião da linguagem que nomeará o real: “Depois 
a noite, corpo imenso.../ e a palha do meu nome... / Que verso te recompõe? / Que fibra te comove ainda?" (Hilst, 2008, p. 244). O fato é que esse poeta preso a uma "noite infinitamente escura" é o mais frágil dos arquétipos frente à barbárie. $O$ padre e sua fé, o estudante e sua razão, o carcereiro e seu pessimismo quase ateu permanecem, na medida do possível, firmes. No entanto, o poeta, aquele que é apenas um corpo, frágil corpo desejante de um novo corpo, corpo que é um "envoltório da vontade" sucumbe. O século, voluntarista, vitalista e nostálgico é excessivo para o poeta, que se esvai. Uma canção, a derradeira canção, é cantada pelos outros personagens quando o Poeta morre:

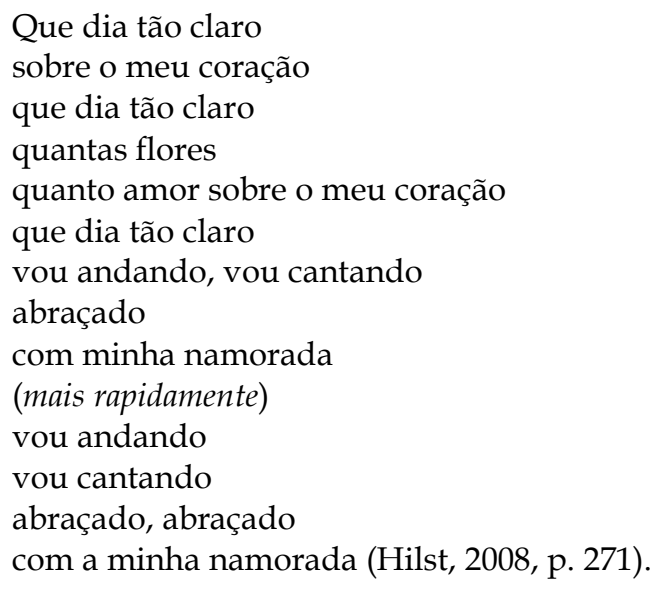

O dia tão claro que não virá, que talvez não se estabeleça mais sobre o século da besta. Na análise que Badiou (2007, p 47) faz de um poema de Mandelstam, o filósofo nos diz que subjetivamente o poeta russo fala que estamos todos com um sorriso insensato. $\mathrm{O}$ sorriso advém do fato de estarmos no umbral, e o insensato é porque o umbral sendo intransponível é impossível sorrir. "Vai-se da vida, da esperança (sorriso) à ausência de sentido do real (insensato). Não seria isso a máxima subjetiva do século?" Em As aves da noite, o poeta morre antecipadamente, mas morre ouvindo um canto insensato, um canto que une todos os arquétipos estabelecidos na peça. Insensatez que faz o SS, ao retirar o corpo do poeta da cena, vilipendiar um poema de Goethe:

SS (empurrando com pé o Padre Maximilian ajoelhado, junto ao Poeta. Como o Padra não se move, agarra-o pela batina e afasta-o): Sai, corvo, 
sai. Vamos ver, vamos ver. (com a ponta da bota sacode o corpo do Poeta várias vezes) Vamos, levante-se porco.

MAXIMILIAN (com voz firme): Ele é um poeta.

SS: Um poeta?: Muito bonito... Hans, leva pra fora, leva pra fora o porco poeta. (Todos se aproximam muito do Poeta) Para trás, para trás. (o ajudante afasta todos com violência) Vamos, todos cantando, cantando, la, la, ra, la... Não querem mais cantar? Pena, pena (Hans começa a arrastar o corpo do Poeta para fora) Então um poeta... muito bonito... nós também temos grandes poetas... Espera um pouco Hans. (começa a dizer lentamente)

Sobre todos os cimos

$\mathrm{O}$ repouso

Sobre todos os cumes

Apenas leve sopro.

Continua comigo Hans (Os dois juntos)

Calam os pássaros na mata

Espera, pois, e em breve

Também descansarás.

(vão saindo, o SS dá risadas discretas e Hans só sorri) Muito bonito... muito bonito... (pausa longa) (Hilst, 2008, p. 272).

Eis a "Wanderers Nachtlied", a "Canção noturna do viandante" de Goethe, tida por Emil Staiger (1974, p 19) como "um dos exemplos mais puros do estilo lírico" usada pelos nazistas, justamente, para aniquilar qualquer lirismo da cena, para dizer que não adianta nada se escudar atrás do predicado de poeta, porque eles também têm seus poetas, também sabem o que é a beleza, o lirismo, também sabem que a canção noturna do viandante será colocada à prova e será interrompida pela força desproporcional de quem detém o poder.

Com a retirada do corpo do poeta da cena, o que temos são os outros espectros lutuosos agarrados aos seus fios de esperança e revolta, debatendo-se cada vez mais, não apenas com a fome e o desespero que carregam, mas com as ideias dos outros: o Carcereiro insiste na ideia de que Deus não é inocente, e não tem nada a ver com eles. A Mulher diz que põe a mão nos corpos, mas é inocente. O Padre insiste na ideia de que Deus é inocente, e que o Carcereiro o encontrará pelo martírio que está vivendo. O Joalheiro fala de seu trabalho, de como colocava pedras menores próximas das raras e aquelas ganhavam brilho. A cena prossegue em sua tensão máxima, muito devido ao Carcereiro, que a movimenta, sempre questionando, 
exigindo uma resposta dos "planos de Deus". Os outros estão resignados pela fé, menos ele que não se conforma e que entra em conflito físico com o Padre:

CARCEREIRO (com ironia): O Padre Maximilian acha que tem, não é? Ele vai nos dizer agora o motivo dessa carnificina. (aproxima-se agressivo de Maximilian) Você vai me dizer nem que eu tenha que te obrigar. (sacode Maximilian) Vamos, Maximilian, qual é a resposta do teu Deus?

A mulher intervém

MULHER (para o Carcereiro): Você parece o demônio. Afaste-se dele.

CARCEREIRO: Qual é a resposta? Fala! (sacode Maximilian várias vezes) (Hilst, 2008, p. 276).

Sem respostas, sem motivos, sem sentido algum, o Carcereiro se torna o personagem mais desamparado, porque lhe foi retirado qualquer base, qualquer esperança. Ele só não se torna um muçulmano, porque ainda tem em si a chama da revolta, ainda tem o grito contra o deus de Maximilian, que se ofereceu em sacrifício para a salvação da humanidade. Hannah Arendt (1994, p. 47) diz que "não há dúvida de que é possível criar condições sob as quais os homens são desumanizados tais como os campos de concentração, a tortura, a fome -, mas isso não significa que eles se tornem animais". Assim, tendo o ódio, a vítima da violência ainda não se desumaniza, pois o ódio não seria uma reação à miséria ou ao sofrimento: "o ódio aparece apenas onde há razão para supor que as condições poderiam ser mudadas, mas não são. Reagimos com ódio apenas quando nosso senso de justiça é ofendido" (Arendt, 1994, p. 47). O Carcereiro, em sua contínua necessidade de entender e de expor seu ódio, ou mesmo o Poeta, que desejou não morrer em amor, mas que o ódio crescesse nele, agem de acordo com aquilo que Hannah Arendt (1994, p. 48) diz quando, em certos momentos, "a violência - o agir sem argumentar, sem o discurso ou sem contar com as consequências - é o único modo de reequilibrar as balanças da justiça." Enquanto para o Padre toda a situação que estão passando é uma prova de amor, para o Carcereiro, isso seria a ausência de limites desse Deus paradoxal que move a fé de seus companheiros de cela, por isso seu ódio:

CARCEREIRO: Depois... Ele nos colocou aqui. (para Maximilian muito exaltado) Ou você pensa que o teu Deus se ofereceu por nada? Para o Seu próprio gozo... para o Seu próprio gozo. Um 
Deus que escolhe para Ele mesmo o martírio, nada é suficiente, você não vê? $\mathrm{E}$ para que Ele consiga um grande prazer, a nossa fome e a nossa sede não bastam. (começa a bater as próprias costas na parede. Alto-falantes na cela, música) Não bastam, não bastam, por quê? Por quê? (Hilst, 2008, p. 277).

O Carcereiro se desespera ainda mais, raspa o chão. Os outros conseguem acalmá-lo. A cena toda prossegue, cada vez mais intensa e paradoxalmente cada vez mais vazia, pois essas pessoas estão se tornando apenas restos. Talvez apenas Maximilian mantenha-se de alguma forma mais firme, porque é o único que escolheu estar ali, é o que lhe diferencia dos demais: a escolha. Escolha que não foi entendida pelo Poeta e que também não é entendida pelas outras vítimas do acaso. A peça amalgama-se entre as vozes desses detentos e a voz de Hitler, vinda dos alto-falantes em um de seus enérgicos discursos. A Mulher tem uma longa fala sobre a alegria de estar viva, mesmo em momentos terríveis como quando tem que limpar a câmera de gás. Agredido por aquela voz, o Carcereiro agride a Mulher, pois ela insiste na alegria de estar viva, ou seja, essa personagem defende a vida individual como valor máximo, como valor ético que suplanta a todos os outros, algo que o revoltado Carcereiro não admite. Nessa discussão, ausenta-se completamente a poesia, morta há algum tempo, restando apenas a barbárie desses corpos entregues a conflitos éticos que extrapolam o próprio motivo pelo qual estão ali: a insistência na alegria, na fé, na resignação ou na revolta gera o delírio final de As aves da noite. O Estudante começa a entrar num torpor, por perceber que poderá ser esquecido pela História. A Mulher pede que o Carcereiro a toque, só assim poderá se salvar do nojo que sente de si mesma. O Padre entra num transe e fica falando seu texto como se estivesse orando. O Carcereiro começa a se contorcer de dor. Pede para que o Padre sofra com ele. O Padre e a Mulher gritam junto com o Carcereiro. De fora, ouvem-se outros gritos de mulheres sendo estupradas. Toda a cena cresce nesse continuado desespero e delírio, entre imprecações, orações, memórias, pedaços de fala que se arremessam no porão da fome, ora atingindo, ora afagando os personagens. Por fim, Hilda opta por uma premissa que toca o absurdo e cria um contraponto entre o aparente realismo com que vinha tratando a cena até então. Os SS trazem uma coroa de arame farpado. Uma das mais conhecidas representações do martírio de Cristo agora se repete na cena final de As aves da noite: 
SS (aproximando-se de Maximilian, que o encara): Ainda consegue levantar os olhos, Padre Maximilian? Escute... ainda podemos trocar o 5.659 por você. Quer? (pausa) Não quer? (pausa) Eu já sabia. Bem. (mostra um pacote a Maximilian) Sabe o que é isso, Maximilian? É um presente para você. Vamos, abra, não tenha medo. (pausa)

Lentamente Maximilian começa a desembrulhar o pacote.

MAXIMILIAN (acabando de desembrulhar. Vê-se que é uma coroa de arame farpado) Mas... eu não sou digno. Não, eu Não sou digno.

SS (suavemente. Tenta colocar a coroa em cada um): Ah, que pena, Hans, ele não quer o nosso presente. Pena... pena, pena... vamos ver... (para o Joalheiro) Então talvez para você. Imagine que é uma coroa de ouro e de pedras preciosas. (ri. Para o Carcereiro) Ou você que parece estar mais vivo. Pega, não quer? (para o Estudante) E você, criança? As coroas ficam bem nas crianças. Ninguém quer? Ela vai ficar aqui, bem no centro, e vocês... vamos ver uma coisa, façam um círculo, vamos Hans, ajuda, vamos fazer um círculo, assim, assim. (Hans, orientado pelo SS, movimenta os prisioneiros, menos a Mulher, colocando-os em círculo com a coroa no centro. Hans tem dificuldade para formar o círculo, porque todos estão terrivelmente debilitados. É difícil mantê-los em pé.) Um pouco mais pra cá, mais pra lá agora, muito bem, muito bem, pena que não é possível arranjar umas belas cadeiras com pequenas placas... de prata... onde estariam gravados o nome de vocês; Seria um belo ritual, hein, Hans? Ah, agora está bem, um círculo perfeito... muito bonito. (afasta-se para ver o efeito. Para a Mulher, com violência) E você, sai, sai, vai andando.

ESTUDANTE (para a Mulher, urrando): Voltaaaa!! (continua gritando "volta" enquanto o SS agride-o várias vezes, tentando fazê-lo calar)

Durante a agressão do SS, Maximilian tenta interferir mas recebe golpes violentos. A mulher segura com rapidez e desespero as mãos de todos, o Estudante tenta segurar a mulher mas Hans afasta-a violentamente, derrubando-a. A Mulher abraça as pernas de Maximilian, mas é arrastada para fora da cela.

SS: Elas se acostumam com tudo, essas porcas. Com tudo. (pausa. Detém-se junto à porta. Fala suavemente) Daqui por diante, senhores, (lentamente) uma santa madrugada, um santo dia, uma santa madrugada, um santo dia, como uma roda, senhores, uma roda perfeita (fdz com uma só mão um movimento circular cada vez 
mais rápido) Perfeita, infinita, infinita. (riso discreto. Sai abruptamente) (Hilst, 2008, p. 295-297).

Se, conforme disse Badiou, o nazismo foi um movimento racional, pensado, articulado, em As aves de noite, ele se apresenta mais como um exercício concentrado de tortura, de manipulação dos ideais e crenças, que vão se tornando sumamente violentas até que esse final surja. Acontece, ao final da peça de Hilda Hilst, aquilo que Primo Levi denominou como "violência inútil", ou seja, aquele tipo de violência que exacerbava qualquer necessidade de controle ou de manejo dos prisioneiros; era uma violência quase endêmica: "todo induce a pensar que, bajo el Tercer Reich, la mejor elección, la elección impuesta desde arriba, era la que llevaba consigo la mayor aflicción, la máxima carga de sufrimiento físico y moral. El 'enemigo' no sólo debía morir sino morir en el tormento" (Levi, 2000, p. 51). Dessa forma, fazer sofrer o "inimigo" era o ofício de cada dia dos agentes, não havia outro fim, o fim seria esse, impor a degradação, algo que para Levi (2000, p. 53) é a única utilidade da violência inútil: "antes de morir, la víctima debe ser degradada, para que el matador sienta menos el peso de la culpa." Em As aves da noite todos são degradados pela coroa de arame farpado - o Carcereiro, o Joalheiro, o Estudante -, não tanto por questões religiosas, mas, sim, porque foram vítimas do acaso, vítimas da violência inútil dos nazistas e agora estão num ritual religioso que não lhes pertence sendo sacrificados feito cordeiros. E atinge diretamente a Maximilian Kolbe, um padre cuja fé é colocada à prova ao se pedir dele um sacrifício tão alto quanto o que foi imposto a Jesus.

Nessa peça, Hilda propõe uma advertência denunciando não apenas os sistemas totalitários e violentos, mas também dizendo que não adianta se ter apenas fé, amor ou ódio sem que haja poesia. Para Hilda Hilst, As aves da noite sempre vencerão caso não deixemos a poesia vencer.

\section{Referências}

AGAMBEN, Giorgio (2008). O que resta de Auschwitz: o arquivo e a testemunha. Tradução Selvino J. Assmann. São Paulo: Boitempo.

ARENDT, Hannah (1994). Sobre a violência. Tradução de André Duarte. Rio de Janeiro: Relume-Dumará.

BADIOU, Alain (2007). O Século. Aparecida: Ideias \& Letras. 
HILST, Hilda (2008). Teatro completo. São Paulo: Globo.

HILST, Hilda (s.d.). Carta datilografada tendo como destinatários Anatol Rosenfeld. HH.II.III. 6.1.0004. Campinas: Cedae/IEL/Unicamp.

KIERKEGAARD, Soren (s.d.). Temor e tremor. Tradução de Torrieri Guimarães. Rio de Janeiro: Ediouro.

LAPOUGE, Gilles (1966). Neonazismo em ascenção. O Estado de S. Paulo, São Paulo, p. 2, 30 mar.

LEVI, Primo (2000). Los hundidos y los salvados. Tradução Pilar Gómez Bedate. Barcelona: Muchnick.

SLOTERDIJK, Peter (2002). O desprezo das massas. Traduçao de Claudia Cavalcanti. São Paulo: Estação Liberdade.

STAIGER, Emil_(1977). Conceitos fundamentais da poética. Tradução de Celeste Aida Galeão. Rio de Janeiro : Tempo Brasileiro.

WALDMAN, Berta (2007). Sobrevoando Auschwitz: as aves da noite. Arquivo Maaravi: Revista Digital de Estudos Judaicos da UFMG, Belo Horizonte, v. 1, n. 1, p. 24-30, out.

WEIL, Simone (1986). A gravidade e a graça. São Paulo: ECE.

Recebido em abril de 2016.

Aprovado em setembro de 2016.

\section{resumo/abstract/resumen}

\section{A advertência poética de Hilda Hilst em As aves da noite}

Rubens da Cunha

Entre 1967 e 1969, Hilda Hilst escreveu oito peças de teatro, entre elas, As aves da noite, que relata os últimos momentos de seis prisioneiros na cela da fome, num campo nazista. Neste artigo, analisamos As aves da noite como uma peça de advertência sobre o terror imposto por qualquer estado totalitário, não apenas o nazista. A análise foi fundamentada, entre outros, por Alain Badiou, para quem o século XX não cumpriu a promessa da modernidade e a vida só cumpriu seu destino e seu desígnio positivo através do terror e por questões sobre o ódio e a violência dos estados totalitários, pensados por Hannah Arendt.

Palavras-chave: Hilda Hilst, totalitarismo, poesia, teatro. 


\section{Hilda Hilst's poetic warning at As aves da noite}

Rubens da Cunha

Between 1967 and 1969 Hilda Hilst wrote eight plays, including As aves da noite, which details the last moments of six prisoners in a hunger detention cell, in a Nazi camp. In this essay, we analyse As aves da noite as a play that warns about the terror imposed by any totalitarian state. Thus, the article proposes a reading based on concepts of Alain Badiou, for whom the twentieth century did not keep modernity's promise, and life only fulfilled its positive fate through terror. Others concepts used in the analysis are the themes of hate and violence within totalitarian states, as proposed by Hannah Arendt.

Keywords: Hilda Hilst, totalitarianism, poetry, theatre.

\section{La advertencia poética de Hilda Hilst en As aves da noite}

Rubens da Cunha

Entre 1967 y 1969, Hilda Hilst escribió ocho piezas de teatro, entre ellas, As aves da noite, en la cual relata los últimos momentos de seis prisioneros en la celda del hambre, en un campo de concentración nazi. En este artículo, analizamos $A s$ aves da noite como una pieza de advertencia sobre el terror impuesto por cualquier estado totalitario, no solamente el instaurado por el nacionalsocialismo alemán. El análisis fue fundamentado, entre otros pensadores, en Alain Badiou, para quien el siglo XX no ha cumplido la promesa de la modernidad y la vida y por el contrario solamente he cumplido su destino y su designio positivo a través del terror. Nos apoyamos en las ideas de Hannah Arendt para analizar el odio y la violencia de los estados totalitarios.

Palabras clave: Hilda Hilst, totalitarismo, poesia, teatro. 